\title{
MAINSTREAMING HUMAN RIGHTS UNDER NATIONAL AND INTERNATIONAL LAW: LEGAL AND EPISTEMIC QUESTION
}

\author{
Damilola S. Olawuyi*
}

\begin{abstract}
Even though the concept of human rights mainstreaming is not new to public international law, it has recently gained increased recognition as a practical approach for recognizing the linkages between human rights and other social justice issues such as environmental protection. A plenitude of literature have been generated on the need to recognize and enforce human rights standards and norms in a wide range of issues including environment, health, gender, poverty, food, water and refugee protection to mention but a few. Despite the rapid ascendancy of the human rights mainstreaming concept, much attention have not been given to the scope of human rights mainstreaming and the practical aspects of human rights mainstreaming, particularly whether institutions consisting of 'outsiders' to the human rights epistemic community can interpret and enforce human rights obligation. Put simply, do environmentalists, scientists and outsiders to human rights have the capacity to mainstream human rights? This paper examines the scope and tenets of human rights mainstreaming, it then discusses the practical aspects of mainstreaming human rights into policy making, particularly how epistemic concerns on human rights mainstreaming can be addressed in national and international policy design and implementation.

There is virtually no aspect of our work that does not have a human rights dimension. Whether we are talking about peace and security, development, humanitarian action, the struggle against terrorism, climate change, none of these challenges can be addressed in isolation from human rights.

Ban Ki-moon, Secretary-General of the United Nations. ${ }^{1}$
\end{abstract}

Keywords: public international law, human rights education and capacity development,United Nations

\section{Introduction}

Over the last decade, the cross cutting linkages between human rights and many social development themes have gained increased recognition. The human rights community has witnessed a geometric rise in the appeals for human rights recognition for a multitude of social justice issues. Examples of such proposals include: the right to a clean and healthy environment, ${ }^{2}$ the

*LL.M (Calgary), LL.M (Harvard), DPhil. (Oxford), Director for Research, Training and International Development, Institute for Oil, Gas, Energy, Environment and Sustainable Development (OGEES Institute), Afe Babalola University, Ado Ekiti, Nigeria; email: dolawuyi@ ogesinstitute.edu.ng .

${ }^{1}$ See the United Nations Human Rights Mainstreaming Portal, <http://hrbaportal.org/the-un-andhrba> accessed 12 January 2012.

${ }^{2}$ S Turner, A Substantive Environmental Right: An Examination of the Legal Obligations of De- 
right to be cold, ${ }^{3}$ right to sexual pleasure; ${ }^{4}$ the right to be free from poverty; ${ }^{5}$ a right to commit suicide; ${ }^{6}$ a right to sleep; ${ }^{7}$ the right not to be exposed to excessively and unnecessarily heavy degrading, dirty and boring job; ${ }^{8}$ the rights of individuals to permanent peace; ${ }^{9}$ and a right to tourism. ${ }^{10}$ In 2009, the United Nations Development Group launched what is currently the most comprehensive human rights mainstreaming plan within the international development circle - the UNDG Human Rights Mainstreaming Programme (UNDG-HRM). ${ }^{11}$ The UNDG-HRM aims to mainstream human rights norms and standards into the work and activities of all UN agencies and programmes.

The main crux of the propositions by human rights mainstream theorists is the inclusion or integration of human rights norms and practices into social justice issues such as development, environmental protection, health, education, business, safety, government and labour. ${ }^{12}$ Even though, the

cision-Makers towards the Environment (Kluwer Law International 2009); M Paellemarts, 'The Human Right to a Healthy Environment as a Substantive Right' in M Dejeant-Pons and M Paellemarts (eds), Human Rights and the Environment (Council of Europe 2002) 11, 15; S Atapattu, 'The Right to a Healthy Life or the Right to Die Polluted?: The Emergence of a Human Right to a Healthy Environment under International Law' (2002) 16 Tul. Envtl. L.J. 65; J May, 'Constitutionalizing Environmental Rights Worldwide' (2006) 23 Pace Envt. Law Rev. 113; K Ebeku, 'The Constitutional Right to a Healthy Environment and Human Rights Approaches to Environmental Protection in Nigeria: Gbemre v Shell Revisited' (2007) 16(3) Rev. Eur. Community \& Int'l Envtl L. 312.

${ }^{3}$ See L Collins, 'Environmental Rights for the Future? Intergenerational Equity in the EU' (2007)16(3) Rev. Eur. Community Int’l Envtl. L. 321.

${ }^{4}$ Sexual Rights are Fundamental and Universal Rights (A Declaration Adopted by the World Association of Sexual Health in Hong Kong at the 14th World Congress on Sexology, August 26, 1999), <http:// www.assert.org.au/downloads/DecSexualRights.pdf> accessed 23 March, 2010. According to the declaration 'Sexual rights are universal human rights based on the inherent freedom, dignity, and equality of all human beings. Since health is a fundamental human right, so must sexual health be a basic human right. Para. 5 reads that 'Sexual pleasure, including autoeroticism, is a source of physical, psychological, intellectual and spiritual well-being' hence a fundamental right.

${ }^{5}$ See T Pogge (ed.), Freedom from Poverty as a Human Right: Who Owes What to the Very Poor? (OUP 2007).

${ }^{6}$ This includes a right to think about suicide and a right to commit suicide. See L Stevens, 'Suicide: A Civil Right' (2006) < http://www.antipsychiatry.org/suicide.htm> accessed 12 March, 2010. This debate was intensified by the US case of Cruzan v Missouri 497 U.S. 261 (1990) where the court declared that an individual has a right to die. According to the court, people have a right of self-determination, which includes the right to refuse medical treatment, and a right to choose to die. See L Perl, Cruzan V Missouri: A Right to Die (Marshall Cavendish, New York 2007) 11. ary, 2010.

${ }^{7}$ See 'Essays on the Right to Sleep'<http://sleepinghumanrights.blogspot.com/> accessed 10 Janu-

${ }^{8}$ See Galtung and Wirak, 'On the Relationship between Human Rights and Human Needs'(1978) UNESCO Doc. SS-78/CONF.630/4 at 48.

${ }^{9}$ ibid.

${ }^{10}$ See B George and V Varghese, 'Human Rights in Tourism: Conceptualization and Stakeholder's Perspectives' (2009) < http://ejbo.jyu.fi/pdf/ejbo_vol12_no2_pages_40-48.pdf> accessed 24 March 2010.

11 The UNDG was established in 1997 as a coalition of over 32 UN agencies, funds, programmes, and offices, plus five observers that play a role in development. The group meets at least three times yearly to decide on issues related to country level coordination to achieve the internationally agreed development goals, including the MDGs. The UNDG seeks to coordinate, harmonize and align the 32 UN agencies, departments, and programmes that are involved in international development. The group's common objective is to deliver more coherent, effective and efficient programmes within the UN system. See UNDG, available at < http://www.undg.org/index.cfm?P=2> accessed 20 January 2012. The United Nations Environment Programme (UNEP) is a part of the UNDG. For a comprehensive list of members see UNDG Members, <http:// www.undg.org/index.cfm?P=1503> accessed 20 January 2012.

12 See NZAID, Human Rights Mainstreaming (New Zealand Agency for International Development 
question whether all moral claims deserve human rights recognition remains a highly contested issue,$^{13}$ the human rights mainstream paradigm has emerged as an approach that advocates that the protection of those international human rights principles, which took the world many years to foster, must be paramount in policy and decision-making at all levels of government. It is a transformative approach aimed at including human right norms at the decision-making level. Simply put, human rights mainstreaming involves the integration of human rights norms and practices into social justice issues.

Despite the fact that human rights mainstreaming has been espoused and developed by a plethora of UN organizations, regional bodies, and state governments, the idea has remained highly debated. One of the strongest debates is the question on the practical implications of human rights mainstreaming literature, i.e what are the legal and institutional prerequisites for human rights mainstreaming. More importantly, can outsiders to the human rights community effectively implement and enforce human rights principles and norms? ${ }^{14}$ As Fiona notes 'the somewhat vague and nonspecific character of the concept of mainstreaming has probably aided this rapid ascendancy; everyone understands the general idea but no one is sure what it requires in practice.' ${ }^{15}$

This paper examines these debates and provides synoptic responses to them. Part two provides a background on the origin and tenets of the human rights mainstream paradigm. This part will answer the question what does human right mainstreaming entail?; part three examines the epistemic debates on the human rights mainstream paradigm. The paper wraps up in part four with concluding thoughts on the practical aspects of mainstreaming human rights into social justice issues.

\section{Human Rights Mainstreaming: Origin and Meaning}

Human rights mainstreaming is a subset of the legal mainstream paradigm that advocates the harmonization or integration of human rights norms and practices with social justice issues such as development, environmental protection, health, education, business, safety, government and

2009) 4; I Bynoe \& S Spencer, Mainstreaming Human Rights in Whitehall and Westminster (IPPR 1999); E Petersmann, 'From "Negative" to "Positive" Integration in the WTO: Time for "Mainstreaming Human Rights" into WTO Law' (2000) 37 Common Market Law Review 1363-1382; T Pajuste, Mainstreaming Human Rights in the Context of the European Security and Defence Policy (Erik Castre'n Institute 2008)10.

${ }^{13}$ See N Ferreira, 'The Expanding Realm of Human Rights' (2008) 14 Res Publica 57. Ferreira notes that the danger in the sudden proliferation of human rights is that 'when a concept is used in so many different circumstances; its meaning might become confused'. See also C Welman, The Proliferation of Rights: Moral Progress or Empty Rhetoric (Westview Press, 1999) 177-178 where Welman notes that:

...Just as inflation gradually reduces the real value of one's savings because one can now purchase fewer goods and services with the same amount of money, so also the rights inflation in political discourse has devalued any and every public appeal to rights.

See generally, P Alston, Conjuring Up Human Rights: A Proposal for Quality Control (1984) 78. Am . J Int Law 615 where Alston notes that the lists of rights are growing as if they are brought up by magic. He argues for an appellations controlees system or a quality control system through which the long list of 'would be' rights can be examined and pruned.

${ }^{14}$ See M Koskieniemi, 'Human Rights Mainstreaming as a Strategy for Institutional Power' (2010) 1(1) Humanity 47.

${ }^{15}$ See B Fiona, S Nott, and K Stephen 'Mainstreaming: A Case for Optimism and Cynicism', (2002) Feminist Legal Studies 10(3): 299-311. 
labour. ${ }^{16}$ It advocates that the protection of those international human rights principles, which took the world many years to foster, must be paramount in policy and decision-making at all levels of government. It is a transformative strategy aimed at including human right norms at the decision-making level. Simply put, human rights mainstreaming involves the integration of human rights norms and practices into social justice issues such as environmental protection.

The origin of the human rights mainstream movement can be traced to the 1997 United Nations Programme for Reform, launched by the United Nations Secretary General. ${ }^{17}$ The report designates human rights as a crosscutting issue in each of the four substantive fields covered by the United Nations. ${ }^{18}$ The reform programme called on all entities of the UN to 'mainstream human rights norms' into their respective mandates and activities. ${ }^{19}$ The report recommends the extension of human rights activities by the integration of human rights into all principal United Nations activities and programmes. It gives a mandate to UN agencies to fully integrate human rights into their areas of activities. According to the UN Secretary General:

...We must put people at the centre of everything we do...A more peopleoriented United Nations must be a more results-based organization, both in its staffing and its allocation of resources. ${ }^{20}$

This report was followed by the 1998 Report of the Secretary General to the UN Economic and Social Council which also recommended inter alia the: (i) adoption of a 'human rights-based approach' to activities carried out within the respective mandates of components of the United Nations system; (ii) development of programmes/projects addressing specific human rights issues; (iii) reorientation of existing programmes as a means of focusing adequate attention on human rights concerns. ${ }^{21}$

Ever since this wholesale reform programme was launched, the idea of mainstreaming human rights has found significant support in the activities of most UN agencies, the World Bank, regional bodies such as European Union, African Development Bank, Asian Development bank, and even national governments and agencies at the domestic level. ${ }^{22}$ For example, in

${ }^{16}$ NZAID, Human Rights Mainstreaming (New Zealand Agency for International Development $2009)$ 4; I Bynoe \& S Spencer, Mainstreaming Human Rights in Whitehall and Westminster (IPPR 1999); E Petersmann, 'From "Negative" to "Positive" Integration in the WTO: Time for "Mainstreaming Human Rights" into WTO Law' (2000) 37 Common Market Law Review 1363-1382; T Pajuste, Mainstreaming Human Rights in the Context of the European Security and Defence Policy (Erik Castre'n Institute 2008) 10.

${ }^{17}$ United Nations, Renewing the United Nations: A Programme for Reform, Report of the Secretary General, (A/51/1950), July 14, 1997, p. 87,

18 These include peace and security; development cooperation; economic and social affair; and humanitarian affairs. ibid.

${ }^{19}$ For an excellent and detailed account of the history of human rights mainstreaming, see A Frankovits, Mainstreaming Human Rights, The Human Rights-Based Approach and the United Nations System (UNESCO 2005).

${ }^{20}$ United Nations, Renewing the United Nations: A Programme for Reform, Report of the Secretary General, (A/51/1950), July 14, 1997, p. 87.

${ }^{21}$ See UN/UNDOC/GEN/N97/A/51/950/1997. See UNESCO, 'Guidelines for Human Rights-Based Programming Approach' Executive Directive 1998-004; see also J Theis, 'Evolution and Future of Rightsbased Approaches' (Save the Children Sweden 2003) 10.

${ }^{22}$ See T Greiber, M Janki, M Orellana, A Savaresi-Hartmann and D Shelton, Conservation with Justice: A Rights-Based Approach (IUCN 2009); A Frankovits, Mainstreaming Human Rights, Human Rights 
response to the UN Secretary's Reform Programme, UNESCO in 2003 adopted its Strategy on Human Rights to 'strengthen...the promotion and protection of human rights through the application of a coherent and Organization-wide vision of human rights.'23 The UNESCO Strategy proposed the development of a 'phased plan to mainstream human rights into all of UNESCO's programmes and activities on the basis of human rights instruments and the conclusions of treaty monitoring bodies.' ${ }^{24}$ The need to mainstream human rights in decisionmaking at all levels of governance has also been identified as top priority by the United Nations High Commissioner for Human Rights. ${ }^{25}$

In 2005, Heads of Governments and world leaders at the United Nations World Summit, resolved to integrate the promotion and protection of human rights into national policies and to develop and support human rights mainstreaming strategies. They noted that 'the respect for and promotion and protection of human rights is an integral part of effective work towards achieving the Millennium Development Goals'. The summit also recognised that human rights, development and peace and security are the three related pillars of the United Nations system. ${ }^{26}$ According to the summit outcome:

We resolve to integrate the promotion and protection of human rights into national policies and to support the further mainstreaming of human rights throughout the United Nations system, as well as closer cooperation between the Office of the United Nations High Commissioner for Human Rights and all relevant United Nations bodies. ${ }^{27}$

The UNDG Human Rights Mainstreaming Programme (UNDG-HRM) launched in 2009 by the United Nations Development Group adds further impetus to attempts to mainstream human rights into the work of international development agencies. ${ }^{28}$ The UNDG-HRM specifically aims to mainstream

Based Approach and the United Nations System (UNESCO 2006); C Nyamu-Musembi, and A Cornwall, 'What is the 'Rights-Based Approach' all about? Perspectives from International Development Agencies' (2004) IDS Working Paper 234, K Svadlenak-Gomez, 'Human Rights and Conservation: Integrating Human Rights in Conservation Programming' 48 (USAID 2007); I VeneKlasen, 'Rights-Based Approaches and Beyond: Challenges of Linking Rights and Participation' (2004) IDS Working Paper 235; J Theis, 'Promoting Rights-based Approaches: Experiences and Ideas from Asia and the Pacific' (2004) CRIN Working Documents www.crin.org/docs/resources/publications/hrbap/promoting.pdf accessed 15 July, 2010; I Hamm, Brigitte, 'A Human Rights Approach to Development' (2001) Human Rights Quarterly 23: 1005-31; G Castillo and M Brouwer, 'Reflections on Integrating a Rights Based Approach in Environment and Development' (2007) in Conservation and Human Rights, CEESP/IUCN http://cmsdata.iucn.org/downloads/pm15.pdf accessed 15 May 2010.

${ }^{23}$ UNESCO, Strategy on Human Rights, Adopted by the 32nd UNESCO General Conference 2003

(Document 32 C/57) <http://unesdoc.unesco.org/images/0013/001316/131627e.pdf> accessed 23 February 2012.

24 ibid.,

${ }^{25}$ The Commissioner called for the reform of the Human rights secretariat so as to be the centre of mainstreaming human rights within the UN systems. See U.N. Office of the High Commissioner for 'Human Rights, Mainstreaming Human Rights' < http://www.unhchr.ch/development/mainstreaming-01.html> accessed 23 January 2012.

${ }^{26}$ See UN World Summit, Outcome Document (2005) < http://daccess-dds-ny.un.org/doc/UNDOC/ GEN/N05/487/60/PDF/N0548760.pdf?OpenElement> accessed 12 January 2012.

${ }^{27}$ Emphasis mine. See Para. 126, UN World Summit, ibid.

${ }^{28}$ The UNDG was established in 1997 as a coalition of over 32 UN agencies, funds, programmes, and offices, plus five observers that play a role in development. The group meets at least three times yearly to decide on issues related to country level coordination to achieve the internationally agreed development goals, including the MDGs. The UNDG seeks to coordinate, harmonize and align the 32 UN agencies, departments, and programmes that are involved in international development. The group's common objective is 
human rights norms and standards into the work and activities of all UN agencies and programmes. The UNDG-HRM seeks to further institutionalize human rights mainstreaming efforts in the UN development system and to strengthen system-wide coherence, collaboration and support. It provides the platform for a coordinated and coherent UN system-wide approach towards the integration of human rights principles and international standards into operational activities for development. In 2011, the UNDG-HRM released a comprehensive action plan on how human rights mainstreaming could be achieved within UN systems. ${ }^{29}$ The plan seeks to strengthen coherence in human rights mainstreaming policies and practices across UN systems; enhance the adoption of a human rights based approach (HRBA) within UN systems and teams; enhance UN system-wide knowledge codification and sharing on HRM and strengthen capacity, collaboration and policy dialogue on human rights mainstreaming across the UN ${ }^{30}$ Summarily, the UNDG-HRM aims to strengthen UN system-wide policy coherence, advocacy, knowledge sharing and accountability for results in mainstreaming human rights. ${ }^{31}$

Human rights mainstreaming has also received enormous attention from legal scholars and commentators. ${ }^{32}$ McCrudden, Oxford Law Professor and a leading commentator on human rights mainstreaming defines it as the reorganization, improvement, development and evaluation of policy processes, so that a human rights perspective is incorporated in all policies at all levels and at all stages, by the actors normally involved in policymaking. ${ }^{33}$

to deliver more coherent, effective and efficient programmes within the UN system. See UNDG, available at < http://www.undg.org/index.cfm?P=2> accessed 20 January 2012. The United Nations Environment Programme (UNEP) is a part of the UNDG. For a comprehensive list of members see UNDG Members, <http:// www.undg.org/index.cfm?P=1503> accessed 20 January 2012.

29 The UNDG-HRM identifies four broad priorities:

1. Promoting a coordinated and coherent UN system-wide approach towards the integration of human rights principles and international standards into UN operational activities for development;

2. Providing coherent and coordinated support to Resident Coordinators and UN country teams in mainstreaming human rights;

3. Developing a coherent UN-system wide approach, through cooperation and collaboration among UN agencies, to providing support towards strengthening national human rights protection systems at the request of governments; and

4. Contributing to the integration of human rights issues in the overall UNDG advocacy on development agenda and global issues

See UNDG, UNDG Human Rights Mainstreaming Mechanism: Operational Plan 2011-2013 ( November 2011) available at <http://undg.org/docs/12173/UNDG-HRM\%200perationalPlan\%20Nov\%20 2011.pdf> accessed 23 January 2012.

${ }^{30}$ See 'Priority 1: Promoting a coordinated \& coherent UN system wide approach to human rights integration' in UNDG, UNDG Human Rights Mainstreaming Mechanism: Operational Plan 2011-2013 (November 2011), ibid.

${ }^{31}$ ibid. at 12.

${ }^{32}$ See E Petersmann, 'From 'Negative' to 'Positive' Integration in the WTO: Time for 'Mainstreaming

Human Rights' into WTO Law' (2000) 37 Common Market Law Review 1363-1382; T Pajuste, Mainstreaming Human Rights in the Context of the European Security and Defence Policy (Erik Castre'n Institute 2008); F Beveridge, S Nott, and K Stephen 'Mainstreaming: A Case for Optimism and Cynicism', (2002) 10(3) Feminist Legal Studies 299-311; J Squires, 'Is Mainstreaming Transformative? Theorizing Mainstreaming in the Context of Diversity and Deliberation' (2005) 12(3) Social Politics: International Studies in Gender, State \& Society 366-388; J Theis, 'Evolution and Future of Rights-based Approaches' (Save the Children Sweden 2003) 10; P Alston, Resisting The Merger And Acquisition Of Human Rights By Trade Law: A Reply To Petersmann, (2002) 13(8) EJIL 815; M Koskieniemi, 'Human Rights Mainstreaming as a Strategy for Institutional Power' (2010) 1(1) Humanity 47.

${ }^{33} \mathrm{~J}$ C McCrudden, 'Mainstreaming Human Rights' in Colin Harvey (ed), Human Rights in the Community: Rights as Agents for Change (Hart, 2005); J C McCrudden, 'Mainstreaming Equality in Northern 
Clark defines it as a social justice-led approach to policymaking in which human rights principles, strategies and practices are integrated into the work of government and other public bodies..$^{34}$ It has been framed as a new, better, revolutionary strategy, and a dominant policy framework aimed at reducing the gap between policy intentions and actual results; and as 'a wonder drug' for equal opportunities in international law. ${ }^{35}$ Harvey describes it as the task for the century and as a revolutionary strategy for an effective enforcement and implementation of international human rights standards. According to Harvey:

...As the human rights movement moves forward in this new century, we all must turn to effective enforcement and implementation of international standards. Mainstreaming human rights norms is the task for this century. Human rights lawyers should engage with other fields of knowledge in order to advance these ends. Human rights law must matter, not simply to individual litigants, but to the vast array of oppressed individuals and groups. Making human rights law matter in a concrete sense to others engaged in connected struggles (those working on participatory models of development, for example) to achieve the practical realisation of the ideals of human rights law. ${ }^{36}$

Human rights mainstreaming seeks to promote the protection and fulfillment of existing international human rights by upholding the reflection of human rights norms in policymaking. The current robust principles of international human rights law came about after several years of intense campaigns against societal oppressions and injustices. ${ }^{37}$ As such, what human rights mainstreaming seeks to achieve is to ensure that the ideas and spirits behind human rights law, which are that of liberty, equality and fraternity, are permanently enshrined in human consciousness, by establishing policies that create the appropriate conditions for the enjoyment of human rights. ${ }^{38}$ According to the ICCPR, 'the ideal of free human beings enjoying civil and

Ireland 1998-2004: A Review of Issues Concerning the Operation of the Equality Duty in Section 75 of the Northern Ireland Act 1998' in E McLaughlin and N Faris (eds), Section 75 Equality Duty: An Operational Review (North Ireland Office 2004).

${ }^{34}$ T Clark and F Crepeau, 'Mainstreaming Refugee Rights: The 1951 Refugee Convention and International Human Rights Law' (1999) 17 Netherlands Quarterly on Human Rights, 389-390.

${ }^{35}$ F Beveridge, S Nott, and K Stephen 'Mainstreaming: A Case for Optimism and Cynicism' (2002) Feminist Legal Studies 10(3): 299-311.

${ }^{36}$ J Harvey, 'Review Essay: Gender, Refugee Law and the Politics of Interpretation' (2000) IJRL $12(680)$.

${ }^{37}$ Human rights are a product of philosophical debates that have raged for over two thousand years. The debates have focused on a search for moral standards of political organization and behaviour that are independent of the contemporary society. For an excellent overview of the history of human rights, see J Shestack, 'The Philosophical Foundations of Human Rights' in J Symonides (ed.), Human Rights Concepts and Standards (Ashgate 2000) 31-56; A Heard, 'Human Rights: Chimeras in Sheep Clothing?' (1997) $<$ http://www.sfu.ca/ aheard/intro.html> accessed 12 December, 2011. See also J Manique, 'Universal and Inalienable Human Rights: A Search for Foundations' (1990) 12 Human Rights Quarterly 465-485.

${ }^{38}$ Theorized by Jean-Jacques Rousseau in the Social Contract as the basis of human rights, the slogan of 'Liberty, Equality and Fraternity' has found its way into the Constitutions of many nations including France, India, Haiti, Chad, Gabon and Niger. Also Article 1 of the UDHR states that: 'All human being are born free and equal in dignity and rights. They are endowed with reason and conscience and should act towards one another in a spirit of brotherhood'. See Universal Declaration of Human Rights, adopted 10 de.1948, G.A Res. 217A9III), 3 UN GAOR, UN Doc. A/810 at 71 (1948). See also C Wraight, Rousseau's The Social Contract: A Reader's Guide (Continuum Books 2008). 
political freedom and freedom from fear and want can only be achieved if conditions are created whereby everyone may enjoy his civil and political rights, as well as his social, economic and cultural rights' ${ }^{39}$ Human rights mainstreaming seeks to ensure that these conditions are put in place through the design of right-based policies. Mainstreaming advocates for the enactment of law and the building of institutions that promote, respect, and protect human rights. As law and institutions are vital conditions for the enjoyment of human rights, the mainstream paradigm seeks to ensure that these conditions are permanently in place. As the United Nations High Commissioner for Human Rights rightly noted:

...Mainstreaming human rights in the UN system is not just a mandate for me as the High Commissioner, but a common endeavour for all UN agencies and staff...Over the last decade, there has been significant progress in mainstreaming human rights in the work of the UN system. An increasing number of UN agencies are not only integrating human rights into their internal policies, but also actively advocating for human rights through their mandated work - on the rights of people affected by HIV, on the rights to food, education, health and shelter, and on the fundamental rights of workers...human rights are no longer add-ons to long list of other priorities, but a foundation on which they can build the UN's coherence and comparative advantages. ${ }^{40}$

Generally, the international community is arguably recognizing the need for an integrated approach to development that mainstreams human rights safeguards as a foundation for international policy making. More than before, UN agencies are increasingly playing important roles to ensure that respect for human rights are incorporated into efforts aimed at addressing issues such as climate change. The importance of this new drive is that human rights are not only recognised when there is a problem, instead respect for human rights form part of the rules of the game in the design of international legal regimes.

\section{A. Tenets of Human Rights Mainstreaming}

A fundamental purpose of human rights mainstreaming is to develop 'a human rights culture' in international, regional and national governance. ${ }^{41}$

${ }^{39}$ See Preamble to the International Covenant on Civil and Political Rights, adopted 16 Dec.1966, entered into force 23 March 1976, 999 UNTS 171 <http://www2.ohchr.org/english/law/ccpr.htm> accessed 02 January, 2012.

${ }^{40}$ Statement by N Pillay, United Nations High Commissioner for Human Rights at the Launch of the United Nations Development Group Human Rights Mainstreaming Mechanism (UNDG-HRM) Multi-Donor Trust Fund (27 November 2011) <http://www.undg.org/docs/12174/Statement\%20by\%20High\%20 Commissioner\%20for\%20Human\%20Rights-\%20Ms.\%20Navi\%20Pillay.pdf> accessed 23 January 2012.

41 According the to the United Nations, the crux of human rights mainstreaming is to integrate human rights in all development efforts undertaken by UN Agencies, organizations, funds and programmes, in order to ensure that development is participatory, equitable, sustainable and accountable. See Human Rights Council, 'Draft Concept Note: High Level Panel Discussion on Human Rights Mainstreaming' (1 March 2013), Palais des Nations, Geneva, Switzerland); M Wewerinke \& C Doebbler, 'Exploring the Legal Basis of a Human Rights Approach to Climate Change' 2011 (10) Chinese Journal of International Law 141160; I Bynoe and S Spencer, Mainstreaming Human Rights in Whitehall and Westminster (IPPR 1999); see also UNDG, UNDG Human Rights Mainstreaming Mechanism: Operational Plan 2011-2013 (2011) available at <http://undg.org/docs/12173/UNDG-HRM\%200perationalPlan\%20Nov\%202011.pdf> accessed 
Under this paradigm, human rights issues would not only come to the table when there is a violation, infringement or problem. Instead, human rights would always be placed at the table when governmental decisions are made. According to Blackburn, 'human rights should form part of the 'rules of the game' under which the system of politics and government is conducted. ${ }^{42}$ Decisions such as building a new airport, constructing a new road or sports complex, exploiting a natural resource or building a pipeline and constructing a hydroelectric power plant ought to be made with full appraisal of their likely human rights consequences, and with the full participation and inclusion of citizens whose rights would be affected in the decision-making process. Creating a human rights culture would represent a radical shift from a needsbased approach where human rights are treated as 'add ons'; to an approach that enshrines a human rights culture at the heart of policymaking. Under this model, human rights are not relegated to the background; instead human rights issues are placed at the fore of policymaking, actions and resource allocation. ${ }^{43}$

The human rights mainstream paradigm would present an opportunity for citizens to demand from their governments, the respect for and the enforcement of their human rights. This approach would enlighten citizens of their rights and provide them with many opportunities to enforce them. It empowers citizens to demand that governments, all public authorities and private authorities which fulfil public functions ensure that they comply with human rights standards..$^{44}$ Citizens are provided with the information, education and legal assistance to demand the enforcement of their human rights. Under this paradigm, citizens are not mere observers or objects of decision-making, rather, they are active participants, subjects and in fact the most important stakeholders in the decision-making realm. Citizens are empowered to understand their rights to act as active gatekeepers in ensuring that decisions, policies or governmental projects that can affect their human rights do not see the light of the day. As Baros argued:

... a new type of relationship between the individual and state is needed. A full and participatory citizenship would have to be an ideological framework within which the proposed improvements should take place. Greater awareness of legal and political entitlements by citizens and meaningful participation in political life is a precondition for developing a partnership with the government and therefore contributing to a more positive human rights culture. ${ }^{45}$

Human rights mainstreaming is not all about giving individuals a stick with which to beat the State or a voice to compete with state apparatus, rather it seeks to create a society in which rights and responsibilities are properly balanced. ${ }^{46}$ It promotes the establishment of institutions that promote effective relationships and correlations between rights and responsibilities.

\footnotetext{
23 January 2012.

${ }^{42}$ R Blackburn, 'Towards a Constitutional Bill of Rights for the United Kingdom' Pinter.1999 p xxxii.

${ }^{43}$ ibid.

${ }^{44}$ ibid., see also C Harvey, 'Talking about Human Rights' (2004) 5 E.H.R.L.R 500-516.

${ }^{45}$ M Baros, 'A New Human Rights Culture and Deliberate Constitutionalisation' (2007) Hertfordshire Law Journal 5(1), 115.

${ }^{46}$ J Straw, Home Secretary, 'Building a Human Rights Culture', an address delivered at a Civil Service College Seminar, 9 December 1999.
} 
The whole idea is not only about empowering the individual with rights against governmental excesses. Rather, mainstreaming presents what Hunt describes as the 'communitarian conception of a human rights culture' whereby rights and responsibilities are properly balanced ${ }^{47}$ Citizens understand their rights and freedoms and at the same time understand their obligations and duties. According to Hunt:

...it is designed to introduce a culture of rights that is more communitarian than libertarian in its basic orientation. In such a human rights culture, the individual citizen is more than the mere bearer of negative rights against the state, but is a participative individual, taking an active part in the political realm and accepting the responsibility to respect the rights of others in the community with whom he or she is interdependent...It introduces a distinctly social democratic model of human rights protection, combining the protection of individual rights with a role for participative citizens involved in the democratic decision-making in their community. ${ }^{48}$

Straw in his detailed exposition also notes that under human rights mainstreaming, the underlying idea is that rights do not exist in a vacuum:

The culture of rights and responsibilities we need to build is not about giving the citizen a new cudgel with which to beat the State. That's the old-fashioned individualistic libertarian idea that gave the whole rights movement a bad and selfish name. The idea that forgot that rights don't exist in a vacuum; that forgot the relationship between the individual and the group. That's not the culture of rights and responsibilities we want or need. The culture we want is not a litigious collection of individuals and interest groups who see rights as a free good and the Human Rights Act simply as a means of enforcing the rights of individuals against public authorities. The culture we need is one, which is not always soft when an individual's rights are in play. The true culture of rights and responsibilities may actually sometimes require us to be quite robust about an individual's rights to maintain the rights of others. ${ }^{49}$

The human rights mainstream paradigm is a move from individualistic libertarian conceptions of rights as popularized by activists that fail to emphasise the linkages between human rights and duties that are enshrined in international human rights instruments. This paradigm seeks to establish a culture of mutual respect for human rights between citizens and the state and between citizens amongst themselves. Such a community-based method of promoting human rights finds expression in international human rights instruments. For example the preamble to the ICCPR notes that the 'individual, having duties to other individuals and to the community in which he belongs, is under a responsibility to strive for the promotion and observance of the rights recognised in the present Covenant ${ }^{50}$ Article 29 of the Universal Declaration

${ }^{47}$ M Hunt, 'The Human Rights Act and Legal Culture: The Judiciary and the Legal Profession' (1999) 26 (1) Journal of Law and Society 90.; see also R Bellamy, 'Constitutive Citizenship versus Constitutional Rights: Republican Reflections of the EU Charter and the Human Rights Act' in T Campbell, K Ewing \& A Tomkins, (eds.), Sceptical Essays on Human Rights (OUP 2001)15-39.

${ }^{48} \mathrm{M}$ Hunt, ibid.

${ }^{49}$ J Straw, Home Secretary, 'Building a Human Rights Culture', address to Civil Service College seminar, 9 December 1999.

${ }^{50}$ International Covenant on Civil and Political Rights (Adopted 16 December 1966, entered into 
of Human Rights states that 'everyone has duties to the Community in which alone the free and full development of his personality is possible..51 The African Charter on Human and Peoples' Rights, specifically notes that an individual has duties and obligations both to other individuals and to the state. Human rights mainstreaming allows for a balanced mix of rights and duties. Through balanced policy designs, mainstreaming manifests itself in equal measures: the human rights of citizens and their responsibilities to other individuals, the community and to the state. It promotes a human rights culture that is not all about a collection of individuals and interest groups who see human rights as a free good and primarily as a means of enforcing their rights against national authorities without regard to the interests of other individuals and/ or the wider community. ${ }^{52}$

Human rights mainstreaming also advocates the protection of human rights through multi-faceted, multi-dimensional and cross-disciplinary efforts. ${ }^{53}$ The fundamental assumption of human rights mainstreaming is that human rights are relevant in all aspects of human endeavour including environment, arts, business, education, engineering, faith, labour, media, military, public health, public safety, and law enforcement. The mainstream paradigm represents a focal point that allows an effective mixture and fusion of human rights with other sectors. It provides the knowledge, resources and tools that allow practitioners in the diverse fields to understand, take ownership of and apply human rights norms in their areas of activities. It promotes a shared understanding of human rights across diverse sectors and stimulates a clear, common statement of rights and responsibilities that forms the anchor for all policymaking in the respective sectors.

Such an approach allows for holistic and harmonized responses to emerging societal issues, rather than a fragmented, sectoral or demandbased approach. The problem of fragmentation of international law has been well theorized. ${ }^{54}$ Human rights obligations are scattered in a plenitude of treaties and conventions, while there are also countless other international treaties that speak to a broad range of issues ranging from the environment, terrorism, trade, agriculture, tourism, medicine, aviation, war, humanitarian intervention, health, food, water, gender, housing, banking, religion, family and

force 23 March 1976) 999 UNTS 171 (ICCPR).

${ }^{51}$ Universal Declaration on Human and Peoples Rights, adopted on December 10, 1948) G.A. res. 217A (III), U.N. Doc A/810 at 71 (1948).

${ }^{52}$ See United Nations, 'Concept Note: High Level Panel on Human Rights Mainstreaming' (March 012013 ) < www.ohchr.org/.../panel-on-mainstreaming2013_concept_note.docx> accessed 12 April 2013; see also Home Office notes on 'The Human Rights Culture' <http://www.nationalarchives.gov.uk/ERORecords/HO/421/2/hract/hrcult.htm> accessed 12 May 2012.

${ }^{53}$ See M Freeman, Human Rights: An Interdisciplinary Approach (Polity Press 2011) 8-10, see also 89.

${ }^{54}$ See M Young (ed.), Regime Interaction in International Law: Facing Fragmentation (CUP 2012); S Singh, "The Potential of International Law: Fragmentation and Ethics (2011) 24(1) Leiden Journal of International Law 23-43; A Martineau, 'The Rhetoric of Fragmentation: Fear and Faith in International Law' (2009) 22 LJIL 1; M Koskenniemi \& P Leino, 'Fragmentation of International Law? Postmodern Anxieties' (2002) 15 (3) Leiden Journal of International Law 553-579; J Pauwelyn, 'Bridging Fragmentation and Unity: International Law as a Universe of Inter-Connected Islands' (2004) 5 Mich. J. Int'l L. 903; M. Koskenniemi, 'Fragmentation of International Law: Difficulties Arising from the Diversification and Expansion of International Law', Report of the Study Group of the International Law Commission, Finalised by M. Koskenniemi, A/CN.4/L.682. 
culture to mention but a few. Some of these treaties are either overlapping, counter productive or duplicative raising the need for a coordinated and harmonized approach to international law. ${ }^{55}$ An integrated approach as typified by the human rights mainstream paradigm represents a shift from the 'one pipe-at-a-time' approach to a forward-looking, harmonized and holistic approach. Such an approach is important because socio-justice issues are crosscutting and often react with one another, the root causes of societal injustices are also similar. For example the causes of poverty, environmental pollution, health issues, food scarcity and lack of housing can all be traced to governmental inadequacy in recognising and providing certain entitlements needed to enjoy established human rights such as right to life and right to education. As such a human rights mainstream approach recognises that international law obligations interact with one another and that if they must all be respected and fulfilled, there is a need for an 'integrated approach' which takes into account the cross-cutting issues in different treaty regimes. It promotes a coherence of international obligations with respect to human rights and other issues, through a harmonized approach. ${ }^{56}$ Unlike traditional piecemeal approaches, the mainstream approach enables the problems to be identified and causes tackled, rather than merely treating the symptom on a 'as it happens' basis. The fundamental idea is to foster a human rights culture and to spread the human rights message by ensuring that all governmental actions integrate human rights principles.

Despite the fact that human rights mainstreaming has been espoused and developed by a plethora of UN organizations, regional bodies, and state governments, certain practical questions of implementation continue to arise. Generally, much scholarly attention has not been devoted to asking the question, what are the legal and institutional requirements for an effective human rights mainstreaming process? This has led to the charge that human rights mainstreaming has a fuzzy core with less theoretical underpinnings. ${ }^{57}$ As some commentators have argued, 'the somewhat vague and non-specific character of the concept of mainstreaming has probably aided this rapid ascendancy; everyone understands the general idea but no one is sure what it requires in practice, ${ }^{.58}$

The value of the mainstreaming approach would be manifest if its

${ }^{55}$ See H Van Asselt, F Sindico and M Mehling, 'Global Climate Change and the Fragmentation of International Law' (2008) 30 Law and Policy 423, where the authors describe how climate change regimes conflict with pre-existing international law regimes particularly the biodiversity regimes. They argue that an understanding of the institutional aspects of these relationships may allow enhanced political cooperation and coordination. See also M Doelle, 'Linking the Kyoto Protocol and Other Multilateral Environmental Agreements: From Fragmentation to Integration? (2004) 14 Journal of Environmental Law and Practice 75-104.

${ }^{56}$ According to the United Nations, human rights mainstreaming aims to promote a coordinated and coherent UN system-wide approach towards the integration of human rights principles and international standards; and to develop a coherent UN-system wide approach, through cooperation and collaboration among UN agencies. See 'Priorities of the UNDG-HRM' <http://www.undg.org/index.cfm?P=1452> accessed 12 March 2013.

${ }^{57}$ See M Koskieniemi, 'Human Rights Mainstreaming as a Strategy for Institutional Power' (2010) 1(1) Humanity 47.

${ }^{58}$ See M Koskieniemi, 'Human Rights Mainstreaming as a Strategy for Institutional Power' ibid.; see also G Oberleitner, Global Human Rights Institutions (Polity 2007) 45; B Fiona, S Nott, and K Stephen 'Mainstreaming: A Case for Optimism and Cynicism' (2002) 10 (3) Feminist Legal Studies 299-311. 
scope and content are clarified. There is a need to further the conceptual understanding of the human mainstreaming paradigm, by providing a greater understanding of the potential benefits and problems associated with its application within a specific context. ${ }^{59}$ This is our next endeavour.

\section{Practical Questions on Human Rights Mainstreaming}

\section{A. Definitional Questions}

In the literature on human rights mainstreaming, human rights itself remains a contested concept. ${ }^{60}$ The different interpretations of human rights influence human rights mainstreaming efforts. ${ }^{61}$ For example, many scholars fault attempts to mainstream a human right to food or right to water into decision-making processes pointing to their contested legal status under international law..$^{62}$ On the other hand, theorists point to the interdependent and indivisible nature of all human rights to argue that some human rights are pre-requisites for enjoying other rights, and as such all rights must be mainstreamed into policy making. These are debates on the sources and hierarchy of rights. It is pertinent to clarify the meaning we attach to the idea of human rights in general, in order to put human rights mainstreaming into proper context.

Arguably, there is a need for a common understanding by human rights mainstreaming theorists on what human rights should be understood to mean within a specific context. Do we assign the term a natural law meaning or a positivist meaning?, do we consider new generation human rights or do we focus on first generation and more widely accepted rights? These are questions that have not been definitively answered. The result is that administrators are faced with on the ground implementation challenges that tend to challenge their proper understanding of the concept human rights. For example, when advocates speak of climate change rights or environmental rights, some query whether the term 'rights' could be rightly attached to these social justice concepts.

Arguably, a good approach is to consistently define and understand human rights as those inalienable legal entitlements recognized in core international human rights instruments, conventions, and legal instruments under international law. ${ }^{63}$ This conception of rights denies a priori sources

${ }^{59}$ G Oberleitner, Global Human Rights Institutions, ibid., see also J C McCrudden, 'Mainstreaming Human Rights'in C Harvey (ed), Human Rights in the Community: Rights as Agents for Change (Hart 2005), also available at $<$ http://ssrn.com/abstract=568642> accessed 12 April 2011.

${ }^{60}$ A Langlois, 'The Elusive Ontology of Human Rights' (2004) 18(3) Global Society 245; See also D Kennedy, 'The International Human Rights Movement: Part of the Problem' (2001) European Human Rights Law Review 245-267 where Kennedy argues that one of the problems of the human rights movement is that the concept of human rights 'generalizes too much'. See also J Nickel, Making Sense of Human Rights: Philosophical Reflections on the Universal Declaration of Human Rights (University of California Press 1987) 561-2.

${ }^{61}$ See J Shestak 'The Philosophical Foundations of Human Rights' in J Symonides, Human Rights Concepts and Standards (Ashgate, 2000) 33-35.

${ }^{62}$ See N Aryeh, 'Social and Economic Rights: A Critique' (2006) 13(2) Human Rights Brief 1; see also P Alston, 'Resisting the Merger And Acquisition Of Human Rights By Trade Law: A Reply To Petersmann' (2002) 13(8) EJIL 815.

${ }^{63}$ There are ten core international human rights instruments: International Covenant on Civil and Political Rights, Dec. 19, 1966, 999 U.N.T.S. 171 (hereinafter ICCPR); the International Covenant on 
of rights and posits that all human rights stem from what legal institutions prescribe. It contrasts sharply with natural law theories of human rights. ${ }^{64}$ As Kamenka rightly notes, rights are claims that have achieved a special kind of endorsement or legal success, by a legal system, by widespread sentiment or an international order. ${ }^{65}$ This definition aligns with the views that human rights are entitlements that have achieved legal recognition under existing international treaties, conventions, courts, and legal instruments under international law. To avoid confusion of tongues and practical challenges, human rights mainstream theorists must begin to adopt a consensus connotation of rights. Analysis on human rights mainstreaming should arguably focus on human rights that have been endorsed and enshrined in existing legal instruments under international law.

This immediately raises questions on the relative importance of different types of rights under international law. For example, speaking of mainstreaming a human right to food or right to participation may sound outrageous to pundits who question the legal status of such rights in the first place, despite their broad recognition in the ICESCR and other core international human rights instruments. ${ }^{66}$ These are questions that go back

Economic, Social and Cultural Rights, Dec. 16, 1966, 993 U.N.T.S. 3(hereinafter ICESCR); the International Convention on the Elimination of All Forms of Racial Discrimination, Mar. 7, 1966, 660 U.N.T.S. 195 (hereinafter CERD); Convention on the Elimination of All Forms of Discrimination against Women, Dec. 18, 1979, 1249 U.N.T.S. 13 [hereinafter CEDAW]; Convention against Torture and Other Cruel, Inhuman or Degrading Treatment or Punishment, Dec. 10, 1984, 1465 U.N.T.S. 85; Convention on the Rights of the Child, Nov. 20, 1989, 1577 U.N.T.S. 3; International Convention on the Protection of the Rights of All Migrant Workers and Members of Their Families, Dec. 18, 1990, 2220 U.N.T.S. 3; the Convention on the Rights of Persons with Disabilities, Dec. 13, 2006, U.N. Doc. A/61/611.

See OHCHR, 'Core International Human Rights Instruments' <http://www.ohchr.org/EN/ProfessionalInterest/Pages/CoreInstruments.aspx> accessed 12 March 2013.

${ }^{64}$ See J Finnis, Natural Law and Natural Rights (OUP 1980) 280. The doctrine of natural law was popularized and developed by a number of classical Greek philosophers including Aristotle. However it was the work of St Thomas Aquinas (1225-74) that was most notable. In his Summa Theologiae he described natural law as conferring certain immutable rights upon individual as part of the law of God. They were goods or behaviours that were naturally right (or wrong) because God ordained it so. Humans could ascertain what was naturally right by 'right reason' - thinking properly. Hugo Grotius and Samuel von Pufendorf defined natural law as a dictate of right reason. Grotius described international law as laws derived from the will of man and from the principles of nature. Hugo Grotius further expanded on this notion in De jure belli et paci, where he propounded that the Law of Nature is so unalterable, that it cannot be changed even by God himself. According to Hettinger, 'the best description of natural law is that it provides a name for the point of intersection between law and morals. The principal claim of natural law is that what naturally is, ought to be' R Hittinger, 'Natural Law and Virtue: Theories at Cross Purposes' published in R George (ed.), Natural Law Theory Contemporary Essays (OUP 1994) 63; See also R Wacks, Understanding Jurisprudence: An Introduction to Legal Theory (OUP 2005) 15.; J Locke, The Two Treatises of Civil Government (Hollis 1689.), see also R George, 'Natural Law' (2008) 31(1) Harvard Journal of Law and Public Policy 171-96; T Pogge (ed.), Freedom from Poverty as a Human Right: Who Owes What to the Very Poor? (OUP 2007), N Ferreira, 'The Expanding Realm of Human Rights' (2008) 14 Res Publica 57; M Cranston, What are Human Rights? (Taplinger Publishing Co 1973) 36; J Shestak 'The Philosophical Foundations of Human Rights' in J Symonides, Human Rights Concepts and Standards (Ashgate, 2000) 33-35 1988) 127

${ }^{65}$ E Kamenka, 'Human Rights, Peoples' Rights' in J Crawford (ed.), The Rights of Peoples (OUP

${ }^{66}$ Article 11 of the International Covenant on Economic, Social and Cultural Rights recognises the right of everyone to an adequate standard of living. This includes, but is not limited to, the right to adequate food, clothing, housing, and "the continuous improvement of living conditions. It also creates an obligation on parties to work together to eliminate world hunger. It is also enshrined in the 1948 Universal Declaration of Human Rights (Article 25). When in force, the 2009 Optional Protocol to the International Covenant 
to debates on the hierarchy of rights. ${ }^{67}$ We view these artificial bifurcations of rights as unnecessary. An arguably better view is that all human rightspolitical, civil, social, cultural and economic - are equal in importance and none can be fully enjoyed without the other. All human rights are important, indivisible and interdependent whether they relate to civil, political or economic and social issues; and cannot be positioned in a hierarchical order. Denial of one right invariably impedes enjoyment of other rights. This paper therefore argues for an integrated understanding and implementation of all human rights in any mainstreaming process.

As such, in an attempt to resolve the definitional puzzle, we consider that human rights mainstreaming could be understood as integrating those human rights that have been recognised in existing core international human rights instruments into legal regimes on climate change. The human rights mainstream approach should be focused at integrating all endorsed human rights under international law into governmental policies and action plans.

\section{B. Question on Human Capacity and Resources}

Another prominent argument against human rights mainstreaming efforts is whether outsiders can interpret and mainstream human rights? Put simply, do environmentalists, scientists and outsiders to human rights have the capacity to mainstream human rights? Offenheiser and Holcombe posed this question when they wrote that:

Mainstreaming a rights-based approach into our organizations is a complex transition. It cannot simply be decreed and implemented. If sound blueprints are to be drawn from this vision, an organization needs to deepen its understanding of the philosophical principles involved and how they apply on the ground in local development contexts. ${ }^{68}$

For example, do entities such as the Secretariat of the United Nations' Framework Convention on Climate Change (UNFCCC), Ministries of Environment and environmental agencies that comprise mainly of environmental practitioners, have the capacity to accommodate such a complex reform. The UNDP defines capacity as the ability of individuals, institutions, and societies to perform functions, solve problems, and set and achieve objectives in a sustainable manner. ${ }^{69}$ Simply put, do environmental

on Economic, Social and Cultural Rights would makes the right to food justiciable at the international level. The right to participation is recognized in Art. 25 of the International Covenant on Civil and Political Rights (ICCPR).

${ }^{67}$ The term 'hierarchy of rights' has been defined as the idea that certain categories of human rights are more important than others. While some scholars stress the importance of civil and political rights others mostly scholars from the South tend to attach primary importance to economic, social and cultural rights. See H Quane, 'Further Dimension to the Interdependence and Indivisibility of Human Rights? Recent Developments Concerning the Rights of Indigenous People' (2012) 25 Harvard Human Rights Journal; J Donnelly, Universal Human Rights in Theory and Practice (2d ed. Cornell University Press 2003) 27-33; G Teeple, The Riddle of Human Rights (University of Toronto Press 2004) 24; J Nickel, 'Rethinking Indivisibility: Towards a Theory of Supporting Relations between Human Rights' (2008) 30 Hum. Rts. Q. $984,985$.

${ }^{68} \mathrm{R}$ Offenheiser and S Holcombe, 'Challenges and Opportunities in Implementing a Rights-Based Approach to Development: An Oxfam America Perspective’ (2003) 32 Non Profit and Voluntary Sector Quarterly 274.

${ }^{69} \mathrm{C}$ Lopes and T Theisohn, Ownership, Leadership, and Transformation: Can We Do Better For

Capacity Development? (UNDP 2003). 
practitioners or health experts have the ability to interpret human rights norms?

Mcrudden has extensively discussed this question. According to him, these debates arise from epistemic communities and human rights advocates who see human rights interpretation as a task and function for human rights experts only. ${ }^{70}$ He defines an epistemic community as a network of professionals with recognised expertise in a particular domain, and an authoritative claim to knowledge within that domain. They have a shared set of normative beliefs, shared causal beliefs, shared notions of validity, and a common policy enterprise. ${ }^{71}$ The crux of the argument is that the interpretation of human rights instruments should be concentrated in bodies whose primary function is human rights interpretation; otherwise human rights will become domesticated, stripped of their radical promise. ${ }^{72}$ Human rights advocates often regard it as dangerous to place the function of interpreting human rights in the hands of professional administrators. Mcrudden notes that:

The argument runs as follows: the epistemic community that consists of public administration professionals with a predominant non-human rights orientation will have a dominant position of interpretation of their functions. To the extent that human rights values are exogenous to that epistemic community, but are given to such administrators for their interpretation, such values may be underestimated in importance in interpretation, or given an interpretation different to what a human rights body would give them. It is, therefore, better not to try to integrate human rights into governmental decision-making in the way that mainstreaming envisages, because the human rights dimension will lose out. The interpretation of human rights instruments should be concentrated in bodies whose primary function is human rights interpretation, otherwise human rights will become domesticated, stripped of their radical promise. ${ }^{73}$

In essence, Mcrdudden considers as dangerous, proposals to place the task of interpreting and applying human rights norms in the hands of organizations such as the UNFCCC which is composed mainly of professional administrators and scientists who do not belong to the epistemic community of human rights law and who arguably know little or nothing about international human rights. This is based on the notion that since such administrators are not particularly trained or educated in human rights law, their attempt to mainstream human rights might be counterproductive and could lead to the erosion of human rights principles.

Koskieniemi takes these arguments further when he notes that entrusting human rights interpretation to outsiders would further blur the already thinning line between human rights experts and outsiders. ${ }^{74} \mathrm{He}$

\footnotetext{
${ }^{70}$ P Haas, 'Introduction: Epistemic Communities and International Policy Coordination'(1992) 46 International Organization 1-35.

${ }^{71} \mathrm{~J}$ McCrudden, 'Mainstreaming Human Rights' in Colin Harvey (ed), Human Rights in the Community: Rights as Agents for Change (Hart 2005) , also available at < http://ssrn.com/abstract=568642>

${ }^{72}$ J McCrudden, ibid. See also J McCrudden, 'Mainstreaming Equality in Northern Ireland 19982004: A Review of Issues Concerning the Operation of the Equality Duty in Section 75 of the Northern Ireland Act 1998' in E McLaughlin and N Faris (eds), Section 75 Equality Duty: An Operational Review (Northern Ireland Office 2004).

73 ibid.

${ }^{74}$ M Koskieniemi, 'Human Rights Mainstreaming as a Strategy for Institutional Power' (2010) 1(1)
} 
considers that this may lead to a situation whereby any group may present itself as a human rights group by articulating its agenda as a human rights agenda. This may lead to a further devaluation of the human rights currency and the dilution of human rights concepts. Alston also raised this view in his vehement rebuttal of proposals by Petersmann that the World Trade Organization (WTO) administrators should be granted the authority to mainstream human rights into the WTO.$^{75}$ According to Alston, the result of following such an approach would be to hijack international human rights law in a way that would fundamentally redefine its contours and make it subject to libertarian principles. ${ }^{76}$ This he noted could lead to the 'economization' of human rights principles. ${ }^{77}$ Petersmann however responded that such an approach can be enhanced by a radical restructuring of UN organizations to foster global integration. ${ }^{78}$ This would be by proper staffing of institutions with human rights experts who can assist with the human rights mainstreaming process.

Alston's views that outsiders to human rights may find it difficult to properly interpret and mainstream human rights are pertinent and agreeable. They however would not constitute enough reasons for intellectual surrender. As Tallant notes, this epistemic distinction is fuelled by the tendency of actors to remain within the formal confines of their areas of mandate, i.e. of human rights institutions/or within the negotiation circles of the UNFCCC process. $^{79}$ This is due to the absence of a formal agenda or obligations to collaborate between actors; the lack of fluid programmatic activity between intergovernmental agencies for example the United Nations Environment Programme (UNEP) and the Office of the High Commissioner for Human Rights (OHCHR); or between civil society groups where human rights and environmental groups are also divided by agenda differences); there is also the personal unwillingness by actors to collaborate across sectors/agendas spurred by the absence of a formal mandate to do so. As such human rights have no place, visibility, or political support in climate change discussions, while climate change is not a priority issue in the everyday affairs of human rights institutions. According to Tallant, this explains why the Human Right and Climate Change communities presently do not overlap or communicate.

Humanity 47.

${ }^{75}$ E Petersmann, 'From "Negative" to "Positive" Integration in the WTO: Time for "Mainstreaming Human Rights" into WTO Law' (2000) 37 Common Market Law Review 1363-1382; see E Petersmann, 'Time for a United Nations 'Global Compact' for Integrating Human Rights into the Law of Worldwide organizations: Lessons from European Integration (2002) 13 EJIL 621.

${ }^{76}$ P Alston, Resisting The Merger And Acquisition Of Human Rights By Trade Law: A Reply To Petersmann, (2002) 13 EJIL 815.

77 ibid.

${ }^{78}$ For the Alston/ Petersmann debate, see E Petersmann, 'Time for a United Nations 'Global Compact' for Integrating Human Rights into the Law of Worldwide organizations: Lessons from European Integration (2002) 13 EJIL 621; P Alston, 'Resisting The Merger And Acquisition Of Human Rights By Trade Law: A Reply To Petersmann' (2002) 13 EJIL 815; E Petersmann, 'Taking Human Dignity, Poverty and Empowerment of Individuals More Seriously: Rejoinder to Alston'(2002) 13 European Journal of International Law 845-851.

${ }^{79} \mathrm{~J}$ Tallant, 'Forging Stronger Cooperation between Human Rights and Climate Change Communities' (February 2012) United Nations Seminar to Address the Adverse Impacts of Climate Change on the Full Enjoyment of Human Rights 23-24 February 2012 - Palais des Nations, Salle XII - Geneva, Switzerland, < http://www.ohchr.org/Documents/Issues/ClimateChange/Seminar2012/DanielTaillant 24Feb2012. pdf $>$ accessed 12 April 2012. 
He calls for a more conducive policy, economic, and institutional space that would bring about a collaboration and constructive engagement between the two epistemic communities. A space in which actual programmes and projects to address climate vulnerability are designed, financed and implemented together by both communities. ${ }^{80}$

A structural restructuring, which would include appointing human rights experts into UN organizations, regional bodies, ministries and state departments, could boost human rights mainstreaming. For example, for the UNFCCC or the respective Environment Ministry to properly integrate human rights issues into their scope and mandate, there would be a need to appoint people with training and experience in human rights into the secretariat or relevant ministry. This could either be by establishing a separate Human Rights Unit within the secretariat or by expanding the membership of committees and Boards to include a human rights expert. This would ensure that human rights and human rights instruments are understood, internalized, implemented, and enforced. ${ }^{81}$

Human rights education could also be beneficial to policymakers and regulators who are not human rights experts. In a recent development, the United Nations' General Assembly on 19 December, 2011, adopted a Declaration on Human Rights Education and Training which emphasises that human rights education and training is essential for the 'promotion of universal respect for and observance of all human rights and fundamental freedoms for all' ${ }^{82}$ Article 7 (4) provides that states, and where applicable relevant governmental authorities, should ensure adequate training in human rights and, where appropriate, international humanitarian law and international criminal law, of state officials, civil servants, judges, law enforcement officials and military personnel, as well as promote adequate training in human rights for teachers, trainers and other educators and private personnel acting on behalf of the state. Article 11 also provides that:

The United Nations and international and regional organizations should provide human rights education and training for their civilian personnel, and military and police personnel serving under their mandates. ${ }^{83}$

In order to effectively mainstream rights, HRE is essential so that staff can be familiar with human rights standards, including human right laws and their monitoring and implementation mechanisms. ${ }^{84}$ For example, environmental regulators that have not acquired direct and extensive training on human rights could be enlisted for short courses and advanced training on human rights norms. This would provide some basic knowledge necessary to understand and handle mundane human rights issues arising within the

\footnotetext{
80 ibid.

${ }^{81}$ See J Knox 'Linking Human Rights and Climate Change at the United Nations' (2009) 33 (2) Harvard Environmental Law Review 477-498.

${ }^{82}$ United Nations Declaration on Human Rights Education and Training, U.N. Human Rights Council Res. 16/1, in U.N. Human Rights Council, Report of the Human Rights Council on its Sixteenth Session U.N. Doc. A/HRC/RES/16/1 (19 December 2011).

83 ibid.,

${ }^{84}$ Hamm illustrates this with the example of an expert from the German Ministry of Economic Cooperation and Development (BMZ), who notes that development experts in his ministry lack knowledge of human rights and thus they are not in a position to implement the HRBA. See B Hamm, 'A Human Rights Approach to Development' (2001) 23 Human Rights Quarterly 1005-31.
} 
secretariat. For example, there is currently an advanced international certificate course on 'Mainstreaming Human Rights'. ${ }^{85}$ Such a course could provide some level of training and general education on human rights and on how to apply human rights norms. Such training might provide a general understanding of human rights concepts and human rights mainstreaming which could prove sufficient to handle human rights issues such as reporting, verifications and project assessments. It could also reduce the wide gap in knowledge between the human rights epistemic communities and the perceived outsiders. ${ }^{86}$

\section{The Question of Resources}

Similar to the question of expertise and institutional transformation is the question of resources. Realizing and enforcing human rights come with considerable costs. ${ }^{87}$ It has been said that human rights mainstreaming comes with high resource implications, for example the expansion of the current institutions, cost of staffing, training, and programme funding. ${ }^{88}$ According to Mcrudden, due to limited resources and competing budget priorities, the rights based approach that requires a radical transformation may run into implementation problems. ${ }^{89}$ Unlike traditional human rights enforcement approaches, mainstreaming requires the expansion of existing structures and institutions and the building of new ones.

To reduce the cost of a human rights based approach, the UNDP emphasizes an approach which seeks to build on existing capacities and resources. ${ }^{90}$ According to the UNDP, there are always considerable strengths present in terms of human resourcefulness in all organizations, often these can be uncovered and given new life by enlightened management and improved incentives. Implementation should coordinate and integrate linkages with other efforts and reform programmes. Linking new institutions to already existing ones would save some costs and provide free infrastructures to work with. For example, to mainstream human rights norms into existing climate change regimes, there would be a need to leverage on the resources of both the UNFCCC and the United Nations Human rights bodies. One of the missions of the Office of the High Commissioner for Human Rights (OHCHR) is to offer the best expertise and support to the different human rights monitoring

${ }^{85}$ Human Rights Education, Course 1T09: Mainstreaming Human Rights, <http://www.hrea.org/ index.php?doc id=676> accessed 12 March 2012.

${ }^{86}$ UNDP, Capacity Development (Practice Note) (UNDP 2005) 4.

${ }^{87}$ S Fredman, Human Rights Transformed: Positive Rights and Positive Duties (OUP 2008).

${ }^{88}$ See IUCN, Conservation with Justice: A Rights-Based Approach (IUCN 2009); J Theis, 'Promoting Rights-based Approaches: Experiences and Ideas from Asia and the Pacific'(Save the Children 2004) <www.crin.org/docs/resources/publications/hrbap/promoting.pdf > accessed 15 July, 2010; I Hamm and Brigitte, 'A Human Rights Approach to Development' (2001) 23 Human Rights Quarterly 1005-31.

89 J McCrudden, 'Mainstreaming Human Rights' in Colin Harvey (ed), Human Rights in the Community: Rights as Agents for Change (Hart 2005), also available at $<$ http://ssrn.com/abstract=568642 $>$ accessed 12 May 2012.

${ }^{90}$ United Nations, The Human Rights Based Approach to Development Cooperation towards a Common Understanding among UN Agencies (2003) http://www.undg.org/archive docs/6959-<The Human Rights Based Approach to Development Cooperation Towards a Common Understanding among UN.pdf> accessed 12 October, 2010. 
mechanisms in the United Nations system. ${ }^{91}$ The OHCHR supports the work of treaty bodies and assists them in harmonizing their working methods and reporting requirements through their secretariats. OHCHR aims to improve the integration of human rights standards and principles within the UN entities. ${ }^{92}$ For example, leveraging some of the resources, facilities and best practices available from the OHCHR to bolster implementation could strengthen mainstreaming human rights norms into climate change regimes. The emphasis here is on strong inter-agency linkages and partnerships to reduce the cost of mainstreaming and to coordinate efforts. At the national level, it would mean drawing from the robust expertise and structures of human rights commissions to deliver human capacity, training and structures for ministries and departments such as environment, energy or health ministries.

Similarly, appointing a lead committee or creating a specialised office to spearhead the mainstreaming effort could also reduce the cost of mainstreaming. This office would bring together key committees and avoid duplication of roles. It would identify areas of priorities and distribute resources in accordance with the priorities identified. It would also identify institutions or offices that could be compressed and condensed to make room for only necessary offices. Offices that duplicate roles could be scrapped.

\section{Conclusion}

Human rights mainstreaming is a transformative policy framework that provides a process through which human rights are systematically integrated into policy systems, structures and practices. It is an approach that focuses on recognizing, protecting and fulfilling human rights obligations in policy making across all sectors. Its persistent and continuous adoption by international development organizations such as the United Nations, governments at regional and national levels coupled with its rapid ascendancy in scholarly works point to its emergence as a promising approach for ensuring the respect, protection and fulfillment of human rights obligations in policy making.

However, if this approach is to move beyond mere rhetoric, there is a need for strong inter-agency linkages and partnerships to reduce the cost of mainstreaming and to coordinate efforts aimed at fostering the mainstreaming process. There is also a need for human rights education and capacity development. Human rights education could help bridge the gap and aid policymakers and regulators who are not human rights experts. To achieve this, there is a need for a national and regional implementation of the UN Declaration on Human Rights Education and Training which emphasises that human rights education and training is essential for the "promotion of universal respect for and observance of all human rights and fundamental freedoms for all'.93 Article 7 (4) specifically provides that governmental authorities, should ensure adequate training in human rights and, where

\footnotetext{
${ }^{91}$ See UNHCR, Frequently Asked Questions on the Human Rights Based Approach (2005) < http:// www.ohchr.org/en/hrbodies/Pages/HumanRightsBodies.aspx > accessed 12 December 2011.

${ }^{92}$ ibid.

${ }^{93}$ United Nations Declaration on Human Rights Education and Training, U.N. Human Rights Council Res. 16/1, in U.N. Human Rights Council, Report of the Human Rights Council on its Sixteenth Session U.N. Doc. A/HRC/RES/16/1 (19 December 2011).
} 
appropriate, international humanitarian law and international criminal law, of state officials, civil servants, judges, law enforcement officials and military personnel, as well as promote adequate training in human rights for teachers, trainers and other educators and private personnel acting on behalf of the state.

Nationally, a starting point will be to emphasise human rights education and training for officers in relevant ministries and departments including heath, education, environment, sports etc. The cross cutting importance of human rights across these fields means human rights protection is no longer the task for human rights experts alone. HRE is essential so that officers of core ministries can be familiar with human rights standards, including human right laws and their monitoring and implementation mechanisms. Such training might provide a general understanding of human rights concepts and human rights mainstreaming which could prove sufficient to handle human rights issues such as reporting, verifications and project assessments. It could also reduce the wide gap in knowledge between the human rights epistemic communities and the perceived outsiders.

\section{Bibliography}

\section{Books, Articles, Journals}

Alston,P. (1984). Conjuring Up Human Rights: A Proposal for Quality Control.

Alston,P. (2002). 'Resisting the Merger And Acquisition Of Human Rights By Trade Law: A Reply To Petersmann'. EJIL 815.

Aryeh,N. (2006). 'Social and Economic Rights: A Critique'. Human Rights Brief 1.

Atapattu,S. (2002) 'The Right to a Healthy Life or the Right to Die Polluted?: The Emergence of a Human Right to a Healthy Environment under International Law'.

Baros,M. (2007). 'A New Human Rights Culture and Deliberate Constitutionalisation'. Hertfordshire Law Journal

Bellamy,R. (2001). 'Constitutive Citizenship versus Constitutional Rights: Republican Reflections of the EU Charter and the Human Rights Act'. OUP.

Beveridge,F, Nott,S \& Stephen,K. (2002). 'Mainstreaming: A Case for Optimism and Cynicism, Feminist Legal Studies.

Blackburn,R. (1999). 'Towards a Constitutional Bill of Rights for the United Kingdom' Pinter.

Bynoe,I \& Spencer,S. (1999). Mainstreaming Human Rights in Whitehall and Westminster. IPPR.

Cranston,M. (1972). What are Human Rights?. Taplinger Publishing.

Clark,T \& Crepeau,F. (1999). 'Mainstreaming Refugee Rights: The 1951 Refugee Convention and International Human Rights Law'.Netherlands Quarterly on Human Rights.

Collins,L. (2007).“Environmental Rights for the Future? Intergenerational Equity in the $E U^{\prime \prime}$. Eur. Community Int'l Envtl.

Doelle,M. (2004). 'Linking the Kyoto Protocol and Other Multilateral Environmental Agreements: From Fragmentation to Integration?.Journal of Environmental Law and Practice.

Donnelly,J. (2003). Universal Human Rights in Theory and Practice. Cornell University Press. 
Ebeku,K. (2007). 'The Constitutional Right to a Healthy Environment and Human Rights Approaches to Environmental Protection in Nigeria: Gbemre v Shell Revisited' Eur. Community \& Int'l Envtl L.

Ferreira, N.(2008). 'The Expanding Realm of Human Rights'. 14 Res Publica 57

Finnis,J. (1980). Natural Law and Natural Rights. OUP.

Fiona,B. Nott,S \& Stephen,K. (2002). 'Mainstreaming: A Case for Optimism and Cynicism'. Feminist Legal Studies.

Frankovits, A. (2005). Mainstreaming Human Rights, The Human Rights-Based Approach and the United Nations System.UNESCO.

Freeman,M. (2011). Human Rights: An Interdisciplinary Approach. Polity Press.

Galtung \&Wirak. (1978). 'On the Relationship between Human Rights and Human Needs'.UNESCO.

George,R.(2008). 'Natural Law'. Harvard Journal of Law and Public Policy 171-9.

Greiber,T, Janki,M, Orellana, A, Savaresi-Hartmann \& Shelton,D. (2009). Conservation with Justice: A Rights-Based Approach. IUCN.

Haas,P. (1992). 'Introduction: Epistemic Communities and International Policy Coordination'. 46 International Organization 1-35.

Hamm, Brigitte. (2001). 'A Human Rights Approach to Development. Human Rights

\section{Quarterly}

Harvey,C. (2004). 'Talking about Human Rights'

Harvey,J. (2000). 'Review Essay: Gender, Refugee Law and the Politics of Interpretation'

Hittinger,R. (1994). 'Natural Law and Virtue: Theories at Cross Purposes.' OUP.

Hunt, M. (1999). 'The Human Rights Act and Legal Culture: The Judiciary and the Legal Profession.' Journal of Law and Society.

Kamenka,E. (1988). 'Human Rights, Peoples' Rights'. OUP.

Kennedy,D. (2001). 'The International Human Rights Movement: Part of the Problem'. European Human Rights Law Review 245-267.

Koskieniemi,M. (2010).'Human Rights Mainstreaming as a Strategy for Institutional Power'.

Koskenniemi,M \& Leino,P. (2002). 'Fragmentation of International Law? Postmoder Anxieties.' Leiden Journal of International Law.

Koskenniemi,M. 'Fragmentation of International Law: Difficulties Arising from the Diversification and Expansion of International Law'

Knox,J. (2009). 'Linking Human Rights and Climate Change at the United Nations'. Harvard Environmental Law Review 477-498.

Langlois,A. (2004). 'The Elusive Ontology of Human Rights'. Global Society 245.

Locke,J. (1689). The Two Treatises of Civil Government. Holis.

Lopes,C \& Theisohn,T.(2003). Ownership, Leadership, and Transformation: Can We Do Better For Capacity Development?. UNDP.

Manique,J. (1990). 'Universal and Inalienable Human Rights: A Search for Foundations'. Human Rights Quarterly

Martineau,A. (2009). 'The Rhetoric of Fragmentation: Fear and Faith in International Law'

May,J. (2006). 'Constitutionalizing Environmental Rights Worldwide'.

McCrudden,JC. (2004). 'Mainstreaming Equality in Northern Ireland 1998-2004: A Review of Issues Concerning the Operation of the Equality Duty in Section 75 of the Northern Ireland Act 1998'. North Ireland Office.

McCrudden,JC. (2005). 'Mainstreaming Human Rights' in Colin Harvey (ed), Human Rights in the Community: Rights as Agents for Change. 
Nickel,J. (1987). Making Sense of Human Rights: Philosophical Reflections on the Universal Declaration of Human Rights. University of California Press 561-2.

Nickel,J. (2008). 'Rethinking Indivisibility: Towards a Theory of Supporting Relations between Human Rights'30 Hum. Rts. Q. 984, 985.

Nyamu-Musembi,C \& Cornwall,AW. (2004). 'What is the 'Rights-Based Approach' all about? Perspectives from International Development Agencies'

Oberleitner,G. (2007). Global Human Rights Institutions. Polity.

Oberleitner,G. (2011). Global Human Rights Institutions,

Offenheiser,R \& Holcombe,S. (2003). 'Challenges and Opportunities in Implementing a Rights-Based Approach to Development: An Oxfam America Perspective'. 32 Non Profit and Voluntary Sector Quarterly 274.

Paellemarts,M \& Dejeant-Pons,M. (2002). 'The Human Right to a Healthy Environment as a Substantive Right' Human Rights and the Environment. Council of Europe.

Pajuste,T. (2008). Mainstreaming Human Rights in the Context of the European Security and Defence Policy.Erik Castre'n Institute.

Pauwelyn,J. (2004). 'Bridging Fragmentation and Unity: International Law as a Universe of Inter-Connected Islands' (2004). J. Int'l L.

Perl,L. (2007). Cruzan V Missouri: A Right to Die. Marshall Cavendish, New York.

Petersmann,E. (2000). 'From "Negative" to "Positive" Integration in the WTO: Time for "Mainstreaming Human Rights". Common Market Law Review 1363-1382.

Petersmann,E. (2002). 'Taking Human Dignity, Poverty and Empowerment of Individuals More Seriously: Rejoinder to Alston' European Journal of International Law 845- 851.

Petersmann,E. (2002). 'Time for a United Nations 'Global Compact' for Integrating Human Rights into the Law of Worldwide organizations: Lessons from European Integration.

Pogge,T. (2007). Freedom from Poverty as a Human Right: Who Owes What to the Very Poor? OUP.

Shestak,J. (2000). 'The Philosophical Foundations of Human Rights' in J Symonides, Human Rights Concepts and Standards. Ashgate.

Singh,S. (2011). 'The Potential of International Law: Fragmentation and Ethics. Leiden Journal of International Law.

Squires,J. (2005). 'Is Mainstreaming Transformative? Theorizing Mainstreaming in the Context of Diversity and Deliberation'

Straw,J. (1999). 'Building a Human Rights Culture'. Home Secretary.

S Turner, A. (2009). Substantive Environmental Right: An Examination of the Legal Obligations of Decision-Makers towards the Environment. Kluwer Law International.

Svadlenak-Gomez,K. (2007). 'Human Rights and Conservation: Integrating Human Rights in

Conservation Programming'. USAID.

Teeple,G.(2004).The Riddle of Human Rights. University of Toronto Press.

Theis, J. (2003). 'Evolution and Future of Rights-based Approaches'Save the Children Sweden.

Van Asselt,H, Sindico,F \& Mehling,M. (2008). 'Global Climate Change and the Fragmentation of International Law'. Law and Policy.

VeneKlasen,I. (2004). 'Rights-Based Approaches and Beyond: Challenges of Linking Rights

and Participation'

Wacks,R. (2005). Understanding Jurisprudence: An Introduction to Legal Theory. OUP. 
Welman,C. (1999). The Proliferation of Rights: Moral Progress or Empty Rhetoric. Westview Press.

Wewerinke,M. \& Doebbler,C. (2011). 'Exploring the Legal Basis of a Human Rights Approach to Climate Change'.Chinese Journal of International Law.

Young,M. (2012). Regime Interaction in International Law: Facing Fragmentation. CUP. (1997). Renewing the United Nations: A Programme for Reform, United Nations.

(2009). Human Rights Mainstreaming. New Zealand Agency for International Development.

\section{Conventions and Covenants}

Convention against Torture and Other Cruel, Inhuman or Degrading Treatment or Punishment, Dec. 10, 1984, 1465 U.N.T.S. 85.

Convention on the Elimination of All Forms of Discrimination against Women, Dec. 18, 1979, 1249 U.N.T.S. 13. CEDAW.

Convention on the Rights of the Child, Nov. 20,1989, 1577 U.N.T.S. 3.

Preamble to the International Covenant on Civil and Political Rights, adopted 16 Dec.1966, entered into force 23 March 1976, 999 UNTS 171 available at http:// www2.ohchr.org/english/law/ccpr.htm last visited January 2, 2012.

International Covenant on Civil and Political Rights. Adopted 16 December 1966, entered into force 23 March 1976) 999 UNTS 171. ICCPR.

International Covenant on Civil and Political Rights, Dec. 19, 1966, 999 U.N.T.S. 171 ICCPR.

The Convention on the Rights of Persons with Disabilities, Dec. 13, 2006, U.N. Doc. A/61/611.

The International Covenant on Economic, Social and Cultural Rights, Dec. 16, 1966, 993 U.N.T.S. 3. ICESCR

The International Convention on the Elimination of All Forms of Racial Discrimination, Mar. 7, 1966, 660 U.N.T.S. 195. CERD.

The International Convention on the Protection of the Rights of All Migrant Workers and Members of Their Families, Dec. 18, 1990, 2220 U.N.T.S. 3;

United Nations Declaration on Human Rights Education and Training, U.N. Human Rights Council Res. 16/1, in U.N. Human Rights Council, Report of the Human Rights Council on its Sixteenth Session U.N. Doc. A/HRC/RES/16/1 (19 December 2011).

Universal Declaration on Human and Peoples Rights, adopted on December 10, 1948 G.A. res. 217A (III), U.N. Doc A/810 at 71

\section{Websites}

Castillo, G \& Brouwer, M. (2007). 'Reflections on Integrating a Rights Based Approach in Environment and Development'. Available at http://cmsdata.iucn.org/downloads/ pm15.pdf, Last visited May 15, 2010 CEESP/IUCN.

Fredman,S. (2008). Human Rights Transformed: Positive Rights and Positive Duties. OUP.

George,B \& Varghese,V. (2009). 'Human Rights in Tourism: Conceptualization and Stakeholder's Perspectives', available at http://ejbo.jyu.fi/pdf/ejbo vol12 no2 pages 40-48.pdf, last visited March 24, 2010.

Heard,A. (1997). 'Human Rights: Chimeras in Sheep Clothing?' Available at http:// www.sfu.ca/ aheard/intro.html last visited December 12, 2011

McCrudden,JC. (2005). 'Mainstreaming Human Rights' Available at http://ssrn.com/ abstract $=568642$ Last visited April 12, 2011. Hart. 
McCrudden,J. (2005). 'Mainstreaming Human Rights' in Colin Harvey (ed), Human Rights in the Community: Rights as Agents for Change. Available at

http://ssrn.com/abstract=568642 Last visited May 12, 2012. Hart.

Oberleitner,G. (2009). Human Rights Education, Course 1T09: Mainstreaming Human

Rights, Available at http://www.hrea.org/index.php?doc id=676 last visited March $12,2012$.

Stevens,L. (2006). 'Suicide: A Civil Right', available at http://www.antipsychiatry.org/ suicide.htm, last visited March 12, 2010.

Tallant,J. (2012). 'Forging Stronger Cooperation between Human Rights and Climate Change Communities' Available at; http://www.ohchr.org/Documents/Issues/ ClimateChange/Seminar2012/DanielTaillant 24Feb2012.pdf Last visited April 12, 2012.

Theis,J. (2004). 'Promoting Rights-based Approaches: Experiences and Ideas from Asia and

the Pacific.'Available at www.crin.org/docs/resources/publications/hrbap/ promoting.pdf, Last visited July 15, 2010, CRIN Working Documents, Save the Children.

(1999). Sexual Rights are Fundamental and Universal Rights (A Declaration Adopted by the World Association of Sexual Health in Hong Kong at the $14^{\text {th }}$ World Congress on Sexology, available at http://www.assert.org.au/downloads/DecSexualRights. pdf, last visited March 23,2010.

(2003). Strategy on Human Rights,Available at

http://unesdoc.unesco.org/images/0013/001316/131627e.pdf, Last accessed February 23, 2013.

(2003). The Human Rights Based Approach to Development Cooperation towards a Common

Understanding among UN Agencies Available at http://www.undg.org/archive docs/6959-The Human Rights Based Approach to Development Cooperation_Towards_a_Common_Understanding_among_UN.pdf Last visited October 12, 2010. United Nations.

(2005). Frequently Asked Questions on the Human Rights Based Approach. Available at http://www.ohchr.org/en/hrbodies/Pages/HumanRightsBodies.aspx Last visited December 12, 2011.UNHCR.

(2011). UNDG Human Rights Mainstreaming Mechanism: Operational Plan 20112013. Available at http://undg.org/docs/12173/UNDG- $\quad$ H R M \% 20 OperationalPlan\%20Nov\%202011.pdf Last visited January 23, 2012.

(2013). 'Concept Note: High Level Panel on Human Rights Mainstreaming' Available at www.ohchr.org/.../panel-on-mainstreaming2013 concept note.docx Last visited April 12, 2013, United Nation.

'Core International Human Rights Instruments' Available at http://www.ohchr.org/ EN/ProfessionalInterest/Pages/CoreInstruments.aspx Last visited March 12, 2013. OHCR.

United Nations Human Rights Mainstreaming Portal, available at http://hrbaportal. org/the-un-and-hrba , last visited January 12, 2012.

$U N D G$, available at http://www.undg.org/index.cfm?P=2, last visited January 20

'The Human Rights Culture' Available at http://www.nationalarchives.gov.uk/ ERORecords/HO/421/2/hract/hrcult.htm Last visited May 12, 2012. 